\title{
UDC 635.63:631.527:631.544:631.8
}

\section{METHODS OF INCREASING THE YIELD OF FRUITS AND SEEDS OF A CUCUMBER OF A PARTHENOCARPIC TYPE IN GREENHOUSES CONDITIONS}

\author{
Sergienko O.V., Chayuk O.O., Radchenko L.O., Shulgina L.M., Vitanov O.D., Stovbir O.P. \\ Institute of Vegetable and Melon Growing of National Academy of Agricultural Sciences of Ukraine, \\ Instytutska str., 1, vill. Selektsiine, Kharkiv rg., Ukraine, 62478 \\ E-mail: oksana.sergienko71@ukr.net \\ https://doi.org/10.32717/0131-0062-2019-65-76-83
}

The aim of the research. To determine the influence of plant growth regulators on the basis of humic acids and complex microfertilizers on the yield of fruits and seeds of parthenocarpic cucumber Lyric $F_{1}$ in greenhouses conditions and to determine the indicators of their economic efficiency. Methods. Field, statistical. Results. It was established that the use of plant growth regulators: Hydrogumin, Gulliver Stimul, Vimpel Maxi and microfertilizer CompleMet positively affects the formation of productive and generative organs. Thus, the yield of fruits with the use of 3-times extra-root spraying of PGR and microfertilizer plants increased by $1.06-2.48 \mathrm{~kg} / \mathrm{m}^{2}$. The average gain to control $\left(13.22 \mathrm{~kg} / \mathrm{m}^{2}\right)$ at the expense of the application of PGR was $8.00-18.71 \%$. The highest yield of cucumbers was noted in the variant with the use of microfertilizer CompleMet $-15.70 \mathrm{~kg} / \mathrm{m}^{2}$. It was established that treatment of the maternal form of the cucumber hybrid Lyric $F_{1}$ with Hydrogumin and CompleMet does not result in an increase in the number of seeds per plant. However, the yield of seed from one seedling in variants using PGR Hydrohumin and microfertilizer CompleMet, due to their increase in the number and weight of 1000, was higher and was 2.64 and $2.26 \mathrm{~g}$, respectively, with $2.2 \mathrm{~g}$ in the control. The yield of seeds in variants with the use of drugs Hydrogumin and CompleMet was $142.2 \mathrm{~g} / \mathrm{m}^{2}$ and $135.6 \mathrm{~g} / \mathrm{m}^{2}$ respectively at $97.44 \mathrm{~g} / \mathrm{m}^{2}$ in the control. The proposed method of increasing the yield of cucumber seeds in greenhouses conditions can increase the profitability of seed production by $10-25 \%$. The highest profitability ratio of $72 \%$ ensures the application of microfertilizer CompleMet at $47 \%$ under the basic cultivation technology. Conclusions. The results of the research indicate a positive effect of using PGR and microfertilizers to increase the yield of cucumber at $8.00-18.71 \%$ and $39-46 \%$ respectively. The highest yield of cucumber fruit is noted when applying microfertilizer ComplemeMet $-15.70 \mathrm{~kg} / \mathrm{m}^{2}$, seed yield - when using PGR Hydrohumin $-142.2 \mathrm{~g} / \mathrm{m}^{2}$. The expediency of the use of drugs for increasing the productivity of fruits and seeds of cucumber on a number of economic indicators has been proved. The cost-effectiveness of microfertilizer CompleMet in the technology of growing cucumber fruits in greenhouses conditions is $72 \%$, PGR Hydrogumin for hybrid seed production is $167 \%$, respectively.

Keywords: cucumber, plant growth regulators (PGR), yield, fruits, seeds

\section{ПРИЙОМИ ПІДВИЩЕННЯ УРОЖАЙНОСТІ ПЛОДІВ І НАСІННЯ ОГІРКА ПАРТЕНОКАР- ПІЧНОГО ТИПУ В УМОВАХ ЗАХИЩЕНОГО ГРУНТУ}

\author{
Сергіснко О. В., Чаюк О.О., Радченко Л. О., Шульгіна Л. М., Вітанов О. Д., Стовбір О. П. \\ Інститут овочівництва і баштанництва НААН \\ вул. Інститутська, 1, сел. Селекційне, Харківська обл.,Україна, 62478 \\ E-mail: oksana.sergienko71@ukr.net
}

Мета. Виявити вплив регуляторів росту рослин на основі гумінових кислот та мікродобрива на урожайність плодів та насіння партенокарпічного огірка Лірик $\mathrm{F}_{1}$ в умовах захищеного грунту та визначити показники економічної ефективності їх застосування. Методи. Польовий, статистичний. Результати. Встановлено, що застосування регуляторів росту рослин: Гідрогумін, Гулівер Стимул, Вимпел Максі та мікродобрива КомплеМет позитивно впливає на формування продуктивних і генеративних органів. Так, урожайність плодів із застосуванням прийому триразове позакореневого обприскування рослин регуляторами росту і мікродобривом підвищувалася на $1,06-2,48$ кг / м². В середньому приріст до контролю $(13,22$ кг / м²) за рахунок застосування РРP склав $8,00-18,71 \%$. Найви- 
щий показник урожайності огірка відмічено у варіанті з застосуванням мікродобрива КомплеМет 15,70 кг / м². Встановлено, що обробка материнської форми гібрида огірка Лірик $\mathrm{F}_{1}$ препаратами Гідрогумін і КомплеМет не призводить до збільшення кількості насінників на рослині. Проте, вихід насіння з одного насінники у варіантах із застосуванням РРР Гідрогумін і мікродобрива КомплеМет за рахунок збільшення їх кількості та маси 1000 шт., був вищий і склав 2,64 і 2,26 г відповідно, при 2,20 г в контрольному варіанті. Урожайність насіння в варіантах із застосуванням препаратів Гідро-

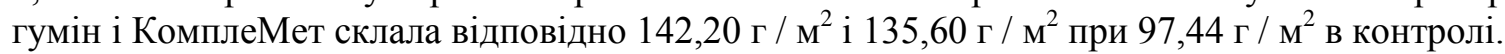

Запропонований прийом підвищення урожайності насіння огірка в умовах захищеного грунту дозволяє збільшити рентабельність виробництва насіння на 10-25\%. Найвищий показник рентабельності 72 \% забезпечує застосування мікродобрива КомплеМет при $47 \%$ за базової технології вирощування. Висновки. Результати досліджень свідчать про отриманий позитивний ефект від застосування РРP та мікродобрив для підвищення урожайності плодів огірка на 8,00-18,71 \% та відповідно на 3946 \% насіння. Найвища урожайність плодів огірка відмічається при застосуванні мікродобрива Ком-

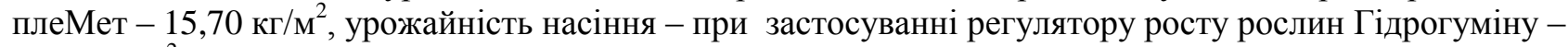
142,20 г/м². Доведено доцільність застосування препаратів для підвищення урожайності плодів та насіння огірка за рядом економічних показників. Рентабельність застосування мікродобрива КомплеМет в технології вирощування плодів огірка в захищеному грунті становить $72 \%$, регулятору росту рослин Гідрогуміну при гібридному насінництві становить відповідно $167 \%$.

Ключові слова: огірок, регулятори росту рослин (РРР), урожайність, плоди, насіння

Актуальність. На сучасному етапі ведення сільського господарства особливого значення набуває питання збільшення врожайності овочевих культур та покращення якості продукції на фоні мінімізації затрат на їх вирощування. Одним $з$ перспективних напрямів підвищення товарної та насіннєвої продуктивності сільськогосподарських культур є використання різноманітних регуляторів росту рослин (Serhiyenko O.V., 2003).

Регулятори росту рослин - це природні або синтетичні сполуки, що в малих концентраціях здатні призводити до значних змін у рості і розвитку рослин. Потрапляючи до організму рослини, вони впливають на обмін речовин і активізують біохімічні процеси, що призводить до підвищення рівня життєздатності рослин, та як наслідок до прискорення проходження фенофаз, збільшення урожайності (Serhiyenko $O . V ., 2003)$. Крім того, регулятори росту підвищують стійкість рослин до біотичних та абіотичних факторів навколишнього середовища (Agapova S.A., 1975; Mamonov Ye.V., 2012) .

Аналіз останніх досліджень і публікацій 3 досліджуваної теми. Головними регуляторами росту рослин (РРР) є фітогормони, які представлені 5 групами: ауксини, гібереліни, цитокиніни, абсцизини, етилен (George E.F., 2008; . Kaur P., et al. 2018).

В насінництві огірка проводилися дослідження 3 визначення ефектів застосування гібереліну на співвідношення жіночих і чоловічих квіток. В 1954 p. Peterson C.E. (Peterson
$S . Y e ., 1960)$ одним із перших встановив, що обробка рослин огірка сорту Шогоин гібереловою кислотою змінює стать в бік утворення чоловічих квіток.

Дослідженнями впливу гібереліну на огірки займалися ряд науковців: Лебедєва А. Т., Тараканов Г.I., Юріна О.В. та ін. (Lebedeva A.T.,1977; Tarakanov G.I.,1981; Yurina O.V., 1980; Farber V.V., 1991).

Етиленпродуценти (етрел, гидрел, етефон, 2хлоретилфосфонова кислота) застосовують для збільшення на гарбузових культурах частки жіночих квіток при використанні рослин в якості материнської форми у гібридному насінництві (Rudich Y.A., 1969; Robinson R.V., 1970; Shennon S., 1979).

У селекції і насінництві огірка поряд з гидрелом застосовувають етефон і дибутилфталат для збільшення жіночих квіток, а суміш нітрату срібла $з$ гидрелом або нітрату срібла з етефон для збільшення чоловічої квіток (Gorokhovskiy V. F., 2002).

Відомо що забезпеченість рослин основними елементами живлення $є$ одним із вирішальних факторів, який обумовлює як товарну так і насіннєву продуктивність рослин овочевих культур. Вплив різноманітних мікроелементів на урожайність насіння огірка досліджували ряд науковців Ваганов А. П., Сорокіна А.Р., Крючков А. П. та ін. (Vaganov A.P., 1970; Machavariani I.F., 1971; Sorokina A.P., 1971; Kryuchkov A.P., 1984). Серед багатьох мікроелементів особливе значення для рослин належить бору, куп- 
руму, марганцю, молібдену, залізу та цинку. Мікродобрива грають важливу роль у багатьох фізіологічних і біохімічних процесах. Встановлено їх значення в прискоренні розвитку рослин і процесах запліднення.

Також рядом вчених досліджувався вплив біологічно активних речовин (препаратів: ДВ47-4, Комплекс 1, Лариксин, Новосил, похідних піридину та ін.) на насіннєву продуктивність огірка та їх післядію. Ними визначена ефективність застосування РРР для підвищення урожайності насіння від 5 до 36,5 \% та доведена відсутність їх післядії на рослини наступного покоління (Ligun A.M., 2000; Kulyakina N.V., 2010; Kulyakina N.V., 2015).

На сьогодні, в умовах захищеного грунту досить широко застосовуються регулятори росту рослин на основі гумінових кислот. Гумінові кислоти екологічно чисті природні сполуки. Вони активізують енергетичний і білковий метаболізми, сприяють кращому запиленню і заплідненню рослин, формують повноцінний урожай. Гумінові кислоти володіють антистресовими властивостями. Це особливо важливо для екологізації сільського господарства. В екстремальних умовах вони нормалізують процеси внутрішньоклітинного метаболізму, зменшують генетичні порушення, стабілізують параметри мітотичного циклу, що адаптує рослини до дії пестицидів, до пересадки і несприятливих факторів навколишнього середовища (Zvedenyuk A.P., 1986). Гумінові речовини є регуляторами росту рослин, проявляючи ауксиноподібні властивості. (Shapoval O.A., 2008)

Мета і завдання дослідження - виявити вплив регуляторів росту рослин на основі гумінових кислот та комплексного мікродобрива на урожайність плодів та насіння партенокарпічного огірка Лірик $\mathrm{F}_{1}$ в умовах захищеного грунту та визначити показники економічної ефективності їх застосування.

Методика та вихідний матеріал. Дослідження проводили впродовж 2016-2018 рр. на експериментальній базі Інституту овочівництва і баштанництва НААН в умовах захищеного грунту плівкових теплиць на площі $200 \mathrm{~m}^{2}$. Об'єктом досліджень був новий партенокарпічний гібрид огірка селекції ІОБ НААН Лірик $\mathrm{F}_{1}$ (Каміла $\left.\mathrm{F}_{1}\right)$. У досліді 3 визначення впливу застосування регуляторів росту рослин та мікродобрив на урожайність плодів огірків використовували наступні препарати:

Гідрогумін, р. - еталон. Регулятор росту рослин, що у своєму складі містить: 55-60\% - гу- мінових речовин, у т.ч. кислоти (25-30\% - гумінові, 20-25\% - фульвові); 5,3-7,5\% - комплекс макро- і мікроелементів; 2,2-2,5\% - низькомолекулярні, органічні та інші біологічно активні сполуки (амінокислоти, органічні кислоти, вітаміни, ферменти, фітогормони, антибіотики) (виробник: «Інститут живлення рослин», Україна).

Гулівер Стимул, p.- регулятор росту рослин, до складу якого входять: гумат калію в перерахунку на гумінові кислоти - не менше 20 г/л, бурштинова кислота -3 г/л, мікроелементи $(\mathrm{Fe}$, $\mathrm{Mn}, \mathrm{Cu}, \mathrm{Zn})$ в хелатній формі з EDTA, інші біологічно активні елементи (гібереліни, ауксини, цитокініни) (виробник: «УКРАВІТ», Україна).

Вимпел Максі, р.- регулятор росту рослин, універсальний комплексний препарат контактно-системної дії для обробки насіння та вегетуючих рослин до складу якого входять: Pormitek $-0-800$ г/л; Vidatamin $-0-800$ г/л; Ferlidol $-0-800$ г/л (виробник: «ДОЛИНА, МПНДП», Україна).

КомплеМет, р.к. - мікродобриво, у своєму складі містить мікро-, макроелементи в хелатній формі призначене для передпосівної обробки насіння та позакореневого підживлення (виробник: «Інститут живлення рослин», Україна).

Дослід передбачав передпосівну обробку насіння у вигляді замочування в розчинах досліджуваних препаратів (експозиція - 12 год.) та триразове обприскування рослин у різні фази вегетації: 3-4 справжніх листки, початку цвітіння та початку плодоношення.

Для визначення впливу регуляторів росту рослин та мікродобрив на насіннєву урожайність огірка виконували триразову обробку рослин препаратами Гідрогумін та КомплеМет на різних етапах онтогенезу рослин: полив у лунку при висадці рослин на постійне місце; позакореневе підживлення рослин у фазу початку цвітіння та фазу масового плодоношення.

Дослідження проводили відповідно до загальноприйнятих методик (Yakovenko K.I., 2001; Gorova T.K., 2001). Економічну ефективність застосування регуляторів росту рослин та мікродобрив для підвищення урожайності визначали за загальноприйнятою методикою (Ulianchenko O.V., 2011). Статистичний обрахунок отриманих результатів досліджень проводили відповідно до методики (Dospekhov B.A., 1985).

Результати та їх обговорення. Першим етапом досліджень було визначення можливого впливу означених препаратів на урожайність 
плодів огірка партенокарпічних генотипів. Результати з визначення впливу регуляторів росту рослин: Гідрогумін, Гулівер Стимул, Вимпел Максі та мікродобрива КомплеМет свідчать про їх позитивний ефект на збільшення урожайності огірка. Відмічається, що урожайність в варіантах із застосуванням РРР підвищувалася у межах 1,06-2,48 кг/м ${ }^{2}$ у порівнянні 3 конт-

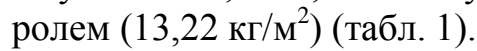

Істотний приріст урожайності у порівнянні із контролем був на варіантах із обробкою препаратами: Гулівер Стимул, Вимпел Максі і мікродобривом КомплеМет та становив 1,63 $2,48 \kappa \Gamma / \mathrm{m}^{2}$. Найвищий показник урожайності плодів огірка відмічався у варіанті зі застосуванням мікродобрива КомплеМет - 15,70 кг/м².

Таблиця 1 Вплив регуляторів росту рослин та мікродобрива на урожайність плодів огірка Лірик $\mathrm{F}_{1}$ (середнє за 2016-2018 pp.)

\begin{tabular}{|c|c|c|c|c|c|}
\hline \multirow{2}{*}{$\begin{array}{l}\text { №№ } \\
\Pi / \Pi\end{array}$} & \multirow[b]{2}{*}{ Варіант } & \multirow{2}{*}{$\begin{array}{c}\text { Норма ви- } \\
\text { трат, } \\
\text { л/га }\end{array}$} & \multirow{2}{*}{$\begin{array}{l}\text { Урожайність, } \\
\text { кг/м }{ }^{2}\end{array}$} & \multicolumn{2}{|c|}{ Приріст урожаю } \\
\hline & & & & $\kappa \Gamma / \mathrm{M}^{2}$ & $\%$ \\
\hline 1 & $\begin{array}{l}\text { Обробка водою (конт- } \\
\text { роль) }\end{array}$ & - & 13,22 & - & - \\
\hline 2 & Гідрогумін (еталон) & 1,5 & 14,28 & 1,06 & 8,00 \\
\hline 3 & Гулівер Стимул & 1,0 & 14,85 & 1,63 & 2,30 \\
\hline 4 & Вимпел Максі & 1,0 & 14,90 & 1,70 & 12,71 \\
\hline 5 & КомплеМет & 1,0 & 15,70 & 2,48 & 18,71 \\
\hline $\mathrm{HIP}_{05}$ & & & 1,60 & & \\
\hline
\end{tabular}

При застосуванні препарату Гідрогумін також спостерігалась тенденція до збільшення урожайності плодів, але перевищення було в межах помилки досліду.

Приріст урожайності за усіма означеними варіантами становив 8,00-18,71\%.
Розрахунки економічної ефективності застосування регуляторів росту рослин та мікродобрива показали, що розроблені прийоми для підвищення урожайності плодів огірка дозволяють знизити собівартість вирощування на 6,5$14,4 \%$ (табл. 2).

Таблиця 2 Економічна ефективність застосування регуляторів росту рослин та мікродобрив на посівах гібрида огірка Лірик $\mathrm{F}_{1}, 2016-2018$ pp.

\begin{tabular}{|l|c|c|c|c|c|c|}
\hline \multicolumn{1}{|c|}{ Показники } & $\begin{array}{c}\text { Одиниці } \\
\text { виміру }\end{array}$ & $\begin{array}{c}\text { Контроль } \\
\text { (базова } \\
\text { технологія) }\end{array}$ & Гідрогумін & $\begin{array}{c}\text { Гулівер } \\
\text { Стимул }\end{array}$ & $\begin{array}{c}\text { Вимпел } \\
\text { Максі }\end{array}$ & КомплеМет \\
\hline Урожайність & кг/м² & 13,22 & 14,28 & 14,85 & 14,90 & 15,70 \\
\hline Виробничі витрати & грн/м² & 44,92 & 45,38 & 45,48 & 45,57 & 45,66 \\
\hline Повна собівартість & грн /кг & 3,40 & 3,18 & 3,06 & 3,06 & 2,91 \\
\hline Зниження собівартості & $\%$ & - & 6,5 & 10,0 & 10,0 & 14,4 \\
\hline Виручка від реалізації & грн & 66,10 & 71,40 & 74,25 & 74,50 & 78,50 \\
\hline Умовно чистий прибуток & грн & 21,18 & 26,01 & 28,77 & 28,92 & 32,84 \\
\hline в т.ч. за рахунок обробки & грн & - & 4,92 & 7,60 & 7,74 & 11,66 \\
\hline Рентабельність, $\%$ & $\%$ & 47 & 57 & 63 & 63 & 72 \\
\hline
\end{tabular}


Умовно чистий прибуток за рахунок розроблених прийомів збільшувався 3 4,92 грн/м² до 11,66 грн/м².

Розроблені прийоми підвищення урожайності насіння огірка в умовах захищеного грунту збільшують рентабельність вирощування на 10-25\%; найвищий показник рентабельності при застосуванні мікродобрива КомплеМет $72 \%$, при $47 \%$ за базової технології вирощування.

Другим етапом досліджень було визначення впливу препаратів на насіннєву урожайність та iï складові партенокарпічного огірка Лірик $\mathrm{F}_{1}$.
Результати досліджень представлені в узагальнюючий таблиці 3.

За результатами досліджень встановлено, що обробка материнської форми гібрида огірка Лірик $\mathrm{F}_{1}$ регулятором росту рослин Гідрогуміном і мікродобривом КомплеМет не призводить до збільшення кількості насінників на рослині, а навіть має тенденцію до зменшення цього показника. Так, у контрольному варіанті кількість насінників на рослину в середньому за роки випробування становила 6,90 шт./росл., а у варіантах з обробкою -6,5-6,7 шт. (табл. 3).

Таблиця 3 Насіннєва урожайність та їі складові гібрида огірка Лірик $\mathrm{F}_{1}, 2017-2018$ pp.

\begin{tabular}{|c|c|c|c|c|c|c|c|c|c|}
\hline Варіант & $\begin{array}{c}\text { Норма } \\
\text { витрат, } \\
\text { л/га } \\
\end{array}$ & Роки & \begin{tabular}{|c|} 
Насінників \\
на росли- \\
ну, шт. \\
\end{tabular} & \begin{tabular}{|c|} 
Вихід \\
насіння, \\
г/нас \\
\end{tabular} & $\begin{array}{c}\% \text { до кон- } \\
\text { тролю }\end{array}$ & $\begin{array}{l}\text { Насіннєва про- } \\
\text { дуктивність, } \\
\text { г/росл. }\end{array}$ & $\begin{array}{c}\% \text { до кон- } \\
\text { тролю }\end{array}$ & $\begin{array}{c}\text { Урожайність } \\
\text { насіння, } \\
\Gamma^{2} \mathbf{M}^{2} \\
\end{array}$ & $\begin{array}{c}\% \text { до кон- } \\
\text { тролю }\end{array}$ \\
\hline \multirow{3}{*}{ Контроль } & \multirow[t]{3}{*}{-} & 2017 & 5,73 & 1,48 & 100 & 8,48 & 100 & 50,88 & 100 \\
\hline & & 2018 & 8,30 & 2,92 & 100 & 24,00 & 100 & 144,00 & 100 \\
\hline & & $\overline{\mathrm{x}}$ & 6,90 & 2,20 & 100 & 16,24 & 100 & 97,44 & 100 \\
\hline \multirow[t]{3}{*}{ Гідрогумін } & \multirow[t]{3}{*}{1,5} & 2017 & 3,80 & 2,47 & 167 & 9,40 & 111 & 56,40 & 111 \\
\hline & & 2018 & 9,50 & 2,81 & 96 & 26,70 & 118 & 228,00 & 158 \\
\hline & & $\overline{\mathrm{x}}$ & 6,70 & 2,64 & 131,5 & 17,70 & 114,5 & 142,20 & 146 \\
\hline \multirow[t]{3}{*}{ КомплеМет } & \multirow[t]{3}{*}{1} & 2017 & 3,82 & 2,22 & 150 & 8,50 & 101 & 59,50 & 117 \\
\hline & & 2018 & 7,36 & 2,90 & 86 & 21,34 & 77 & 211,70 & 147 \\
\hline & & $\overline{\overline{\mathrm{X}}}$ & 6,50 & 2,26 & 118 & 16,90 & 89 & 135,60 & 139 \\
\hline \multirow[t]{2}{*}{$\mathrm{HIP}_{05}$} & & 2017 & 0,1 & 0,5 & & 0,5 & & 0,01 & \\
\hline & & 2018 & 0,1 & 0,1 & & 0,3 & & 0,5 & \\
\hline
\end{tabular}

Однак, слід зазначити, що у контрольному варіанті спостерігався великий відсоток (30\%) насінників без насіння.

Вихід насіння з одного насінника у варіантах із застосуванням препаратів Гідрогумін та КомплеМет був вищим у порівнянні 3 контролем і становив 2,26 г та 2,64 г відповідно, перевищення склало 10-20 \% за рахунок їх кількості та маси 1000 шт.

Насіннєва продуктивність за середніми за роками значеннями у варіанті із застосуванням препарату Гідрогумін становила 17,70 г/росл., що на 1,46 г більше за показник у контролі. У варіанті з застосуванням препарату КомплеМет насіннєва продуктивність становила 16,90 г/росл., що на 0,66 г більше за контроль, при іс- тотному перевищенні контрольного варіанту за роками досліджень.

Урожайність насіння у варіантах із застосуванням препаратів Гідрогумін та КомплеМет

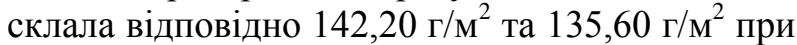

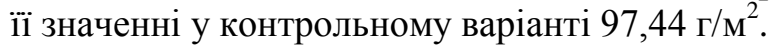

У міру збільшення обсягів виробництва і застосування регуляторів росту рослин зростає необхідність систематичного обліку та контролю ефективності їх дії з метою виявлення найбільш економічно вигідних напрямків їх використання. Розрахунок економічної ефективності застосування рістрегулюючих препаратів на насіннєвих рослинах огірка представлений у таблиці 4. 
Таблиця 4 Економічна ефективність застосування препаратів для підвищення урожайності насіння гібрида огірка Лірик $\mathrm{F}_{1}(2017-2018$ pp.)

\begin{tabular}{|c|c|c|c|c|}
\hline Показники & $\begin{array}{c}\text { Одиниці } \\
\text { виміру }\end{array}$ & $\begin{array}{c}\text { Контроль } \\
\text { (базова техноло- } \\
\text { гія) }\end{array}$ & Гідрогумін & КомплеМет \\
\hline Насіннєва урожайність & $\Gamma / \mathrm{M}^{2}$ & 97,44 & 142,20 & 135,60 \\
\hline Ціна насіння & $\overline{\Gamma р н / \Gamma}$ & 1,20 & 1,20 & 1,20 \\
\hline Виручка від реалізації & грн & 117 & 171 & 163 \\
\hline Збережений урожай & $\Gamma / \mathrm{M}^{2}$ & - & 44,76 & 38,16 \\
\hline Вартість збереженого врожаю & грн & - & 53,71 & 45,79 \\
\hline Повні витрати & $\Gamma \mathrm{pH} / \mathrm{M}^{2}$ & 62 & 64 & 63 \\
\hline Повна собівартість & $\Gamma \mathrm{pH} / \Gamma$ & 0,63 & 0,45 & 0,46 \\
\hline Зниження собівартості & $\%$ & - & 29 & 27 \\
\hline Умовно чистий прибуток, & $\Gamma \mathrm{pH} / \mathrm{M}^{2}$ & 55 & 107 & 100 \\
\hline в т.ч. за рахунок обробки & грн $/ \mathrm{M}^{2}$ & 0 & 52 & 45 \\
\hline Рентабельність & $\%$ & 89 & 167 & 159 \\
\hline
\end{tabular}

Аналіз одержаних даних засвідчив, що у варіанті із застосуванням РРР Гідрогумін на рослинах материнської форми гібрида огірка Лірик $\mathrm{F}_{1}$ збережена урожайність насіння у порівнянні 3 базовою технологією становила $44,76 \mathrm{r} / \mathrm{m}^{2}, \mathrm{y}$ варіанті із застосуванням мікродобрива КомплеМет - 38,16 г/м².

Собівартість 1 г насіння, одержаного у варіанті із застосуванням РРР Гідрогумін становила 0,45 грн, мікродобрива КомплеМет - 0,46 грн, базова технологія - 0,63 грн. Зниження собівартості при застосуванні розроблених прийомів становить $29 \%$ і 27\%, відповідно.

Умовно чистий прибуток за рахунок обприскування рослин материнської форми огірка Лірик $\mathrm{F}_{1}$ РРР Гідрогумін становив 52 грн/ $\mathrm{m}^{2}$, мікродобривом КомплеМет - 45 грн/м². Рентабельність від використання розроблених прийомів на насіннєвих посівах становила $167 \%$ та 159 \% при $89 \%$ за базової технології.

Таким чином, за економічними показниками найбільш ефективним прийомом підвищення насіннєвої урожайності огірка в захищеному грунті є триразова обробка рослин регулятором росту Гідрогумін, що включає: полив у лунку при висадці рослин на постійне місце, позакореневе підживлення у фазу початку цвітіння та масового плодоношення.

Висновки. Таким чином, результати досліджень свідчать про отриманий позитивний ефект від застосування РРР та мікродобрив для підвищення урожайності плодів на $8,00-18,71$ $\%$ та насіння відповідно на 39-46 \%. Найвища урожайність плодів огірка відмічається при застосуванні мікродобрива КомплеМет - 15,70 $\kappa г / \mathrm{m}^{2}$, урожайність насіння - при застосуванні

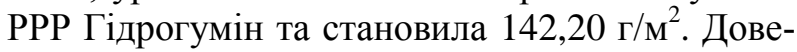
дено доцільність застосування препаратів для підвищення урожайності плодів та насіння огірка за рядом економічних показників. Рентабельність застосування мікродобрива КомплеМет у технології вирощування плодів огірка в захищеному грунті становить $72 \%$, РРР Гідрогумін при гібридному насінництві становить відповідно $167 \%$.

\section{References}

Agapova, S.A. (1975) Osobennosti semenovodstva geterozisnykh gibridov teplichnogo ogurtsa s primeneniyem fiziologicheski aktivnykh veshchestv [Features of seed production of heterotic hybrids of greenhouse cucumber using physiologically active substances] // Doklady TSKHA. Moskva. V. 211. P. 78-83. [in Russian].

Dospekhov, B.A. (1985) Metodika polevogo opyta [Methods of field experience]. Moskva: Kolos. 335 p. [in Russian]

Farber, V.V., Li, YU.S. (1991) Semenovodstvo zhenskikh liniy ogurtsa s ispolzovaniyem fitoregu- 
lyatorov [Seed production of female cucumber lines using phyto-regulators] // $\mathrm{Sb}$. nauch. tr. po prikladnoy botanike, genetike i selektsii. S.Peterburg.: VIR. 145. P. 97-99. [in Russian].

George, E.F. (2008) Plant Growth Regulators I: Introduction; Auxins, their Analogues and Inhibitors. Plant Propagation by Tissue Culture 3rd Edition. Dordrecht : Springer : 175-204, doi: https://doi.org/ 10.1007/978-1-4020-5005-3_5/ [in English].

Gorokhovskiy, V.F. (2002) Selektsiya i semenovodstvo geterozisnykh gibridov ogurtsa universal'nogo naznacheniya [Selection and Seed Breeding of Heterotic Cucumber Hybrids of Universal Purpose]: avtoref. dis. na zdobuttya nauk. stupenya dokt. s.-g. nauk : spets. 06.01 .05 "selektsiya i semenovodstvo" Tiraspol. $25 \mathrm{p}$.

Gorova, T.K., Yakovenko, K.I. (Eds). (2001). Suchasni metody selektsiyi ovochevykh i bashtannykh kultur [Modern methods of selection of vegetable and melon cultures]. Kharkiv: Osnova. 432 p. [in Ukrainian].

Kaur, P., D. Mal, A. Sheokand, Shweta, L. Singh and Datta S. 2018. Role of Plant Growth Regulators in Vegetable Production: A Review. Int. J. Curr. Microbiol. App. Sci. 7(06): 21772183.

https://doi.org/10.20546/ijcmas.2018.706.258 [in English].

Kryuchkov, A.P. (1984) Razrabotka priyemov vozdelyvaniya dal'nevostochnykh sortov ogurtsa na semennyye tseli [Development of methods of cultivation of Far Eastern cucumber varieties for seed purposes] : avtoref. dis. na zdobuttya nauk. stupenya kand. s.-g. nauk : spets. 06.01.05 "selektsiya i semenovodstvo". Khabarovsk. 27 p. [in Russian].

Kulyakina, N.V. (2015) Priyemy povysheniya produktivnosti semennykh posevov i kachestva semyan dal'nevostochnykh sortov ogurtsa Khabar i Yerofey [Receptions of increase of efficiency of seed crops and quality of seeds of Far-Eastern varieties of cucumber Khabar and Erofey] : dissertatsiya kandidata sel'skokhozyaystvennykh nauk. Moskva. 154 p. [in Russian].

Kulyakina, N.V., Kuz'mitskaya, G.A. (2010) Effektivnost primeneniya BAV pri vozdelyvanii ogurtsa na semennyye tseli v usloviyakh Srednego Priumurya [Efficiency of BAS use in the cultivation of cucumber for seed purposes in the conditions of the Middle Priumurye] Agrotekhnicheskiye $i$ biologicheskiye issledovaniya $\mathrm{v}$ sel'skokhozyaystvennom proizvodstve Dalnego Vostoka. Blagoveshchensk. S. 54-59. [in Russian].
Lebedeva, A.T. (1977) Primeneniye gibberellina na ginodietsiynykh formakh ogurtsa $\mathrm{v}$ zashchishchonnom grunte [Application of gibberellin on ginodietic forms of cucumber in protected ground] // Sb. nauch. trudov po selektsii ovoshchnykh kul'tur VNIISSOK. Moskva. T.4. P.54-62. [in Russian].

Ligun, A.M. (2000) Vliyaniye biologicheski aktivnykh veshchestv prirodnogo proiskhozhdeniya na semennuyu produktivnost dalnevostochnykh sortov ogurtsa [Influence of biologically active substances of natural origin on seed productivity of Far Eastern cucumber varieties]: avtoref. dis. kand. s.-kh. nauk. - Blagoveshchensk. 26 p. [in Russian].

Machavariani, I.F., Kurdgelashvili, G.I. (1971) Vliyaniye sposobov vneseniya mikroudobreniy na urozhaynost' i kachestvo semyan ogurtsov [Influence of microfertilizers application methods on yield and quality of cucumber seeds] // Tr. NII zemledeliya Gruzinskoy SSR im. YU. Lomouri, XVIII. P. 27-28.

Mamonov, Ye.V., Starykh, G.A., Goncharov, $A . V$. (2012) Primeneniye regulyatorov rosta rasteniy na kul'turakh semeystva Tykvennyye (Cucurbitaceae) [The use of plant growth regulators on cultures of the Pumpkin family (Cucurbitaceae)] // Izvestiya TSKHA. Moskva: RGAU-MSKHA. V. 2. P. 94-99.

Peterson, S.Ye., Ankhder, L.D. (1960) Induction of staminate flowers on gynoecious cucumbers with gibberellin A3 / Science, V. 131, N 3414. P. 1673-1674.

Robinson, R.V., Whitaker, T.V., Bon, G.W. (1970) Promotin of pistillate fl owering in Cucurbitab y 2-chloroethylphosponic acid / Euphytica, 1970. Vol. 19. № 2. P. 180-183 [in English].

Rudich, Y.A., Galevi, A.KH., Kedal, N. (1969) Increase in femaleness of three cucurbits by treatment with ethrel, an ethylene releasing compound / Bd. 86. H. 1. P. 69-76. [in English].

Serhiyenko, O.V., Lisitsyn, V.M., Dulnyev, V.H. (2003) Vykorystannya novykh ristorehulyuyuchykh preparativ dlya pidvyshchennya urozhaynosti nasinnya ohirka [Use of new growth regulating drugs to increase the yield of cucumber seeds] // Ovochivnytstvo i bashtannytstvo. Kharkiv. V. 48. P. 260-265. [in Ukrainian].

Serhiyenko, O.V., Lisitsyn, V.M., Lisitsyna, R.P. (2003) Vyznachennya pislyadiyi obrobok ristrehulyuyuchymy preparatamy na urozhaynist i yakist plodiv ohirka [Determination of the postoperative effects of treatment with relapsing drugs on the yield and quality of cucumber] // Biolohichni nauky i problemy roslynnytstva. Uman. P. 991993. [in Ukrainian]. 
Shapoval, O.A., Vakulenko, V.V., Prusakova, L.D. (2008) Regulyatori rosta rasteniy [Plant Growth Regulator] // Zashchita i karantin rasteniy. Moskva. № 12. P. 53-88. [in Russian].

Shennon, S., Robinson, R. V. (1979) The use of ethephon to regulate sex expression of summer squash for hybrid seed production. Amer. Soc. Hort. Sci., 104, 674-677. [in English].

Sorokina, A.P. (1971) Vliyaniye mikroelementov na vazhneyshiye fiziologo-biologicheskiye protsessy i produktivnost semennykh ovoshchnykh kultur [The effect of trace elements on the most important physiological and biological processes and productivity of seed vegetable crops] : avtoref. dis. kand. ye.- kh. nauk. Kharkov. 25 p. [in Russian].

Tarakanov, G.I., Agapova, S.A., Gusev, A.M., Borisov, A.V. (1981) Ispolzovaniye rostreguliruyushchikh veshchestv v semenovodstve gibridov teplichnogo ogurtsa [The use of growth regulating substances in seed farming of greenhouse cucumber hybrids] // Biologicheskiye osnovy povysheniya urozhaynosti s.-kh. kultur. - M. P.122-125. [in Russian].

Ulianchenko, O.V., Yarovyi, H.I., Rud, V.P. ta in. (2011). Vyznachennia ekonomichnoi efektyvnosti rezultativ naukovo-doslidnykh robit $\mathrm{v}$ ovochivnytstvi. Kharkiv. 27 p. [in Ukrainian].
Vaganov, A.P., Sorokina, A.P. (1970) Vliyaniye mikroelementov na semennuyu produktivnost' ogurtsov [The effect of trace elements on the seed productivity of cucumbers] // Ovoshchevodstvo i bakhchevodstva. - Kharkov. P. 11-15. [in Russian].

Yakovenko, K.I., Gorova, T.K. (Eds). (2001). Metodyka doslidnoyi spravy $\mathrm{v}$ ovochivnytstvi i bashtannytstvi [Methodology of experimental work in vegetable and melon]. Kharkiv: Osnova. 369 p. [in Ukrainian].

Yurina, O.V., Lebedeva, A.T. (1980) Tekhnologiya elitnogo semenovodstva materinskikh i ottsovskikh form ogurtsa dlya polucheniya vysokoproduktivnykh geterozisnykh gibridov $\mathrm{v}$ plonochnykh teplitsak [The technology of elite seed production of the maternal and paternal forms of cucumber to produce highly productive heterotic hybrids in film greenhouses] // Sb. nauchnykh trudov po selektsii ovoshchnykh kul'tur VNIISSOK. Moskva. № 11. P. 18-25. [in Russian].

Zvedenyuk, A.P., Didenko, I.V., Chavda, N.F. (1986) Ispolzovaniye regulyatorov rosta $v$ semenovodstve ogurtsa i luka [The use of growth regulators in the seed farming of cucumber and onion] // Selektsiya i semenovodstvo ovoshchnykh kultur. Moskva. P. 70-73. [in Russian]. 